\begin{tabular}{|l|l|l|l|l|l|}
\hline J. Tek. Ling & Vol.10 & No.3 & Hal. 257 - 263 & Jakarta, Sept 2009 & ISSN 1441-318X \\
\hline
\end{tabular}

\title{
PEMANFAATAN LIMBAH KULIT SINGKONG, KULIT PISANG DAN KULIT KENTANG SEBAGAI BAHAN PAKAN TERNAK MELALUI TEKNIK FERMENTASI
}

\author{
Sindu Akhadiarto \\ Peneliti di Pusat Teknologi Produksi Pertanian \\ Badan Pengkajian dan Penerapan Teknologi
}

\begin{abstract}
Indonesia as an agricultural country have many agriculture waste that usefull for feed ingredients, contained high energy but low protein. The constraints from the use of those feed ingredients are that they have low nutrient content, low economic value as feed, unavailable continously, hard to handle, need certain facility, need high transportation cost, low storage periode and high toxin contamination. Microbiology can handle those constraints by the use of microbes, which recently used in feed industry. This reseach have goal for improving protein contain of cassava peel, bananas peel and potatos peel which fermented by Aspergillus niger. The methodology done by solid fermentation as ORTSOM method and IRCHA method.Cassava peel, bananas peel and potatos peel sterilized by boiling and nitrogen analyzed by Kjeldahl method. The result show that protein contains of cassava peel, bananas peel and potatos peel increase significantly. $(p<0.05$.) and they can be as substrat for Aspergillus niger medium for industry.
\end{abstract}

Key words : by product, cassava peel, bananas peel, potatos peel, Aspergillus niger

\section{PENDAHULUAN}

\subsection{Latar Belakang}

Pakan adalah salah satu faktor yang sangat menentukan di dalam usaha budidaya ternak, disamping mutu bibit dan tata laksana. Namun, keberhasilan pengembangan berbagai sektor (industri, perumahan, perkebunan dan lain-lain), mengakibatkan terjadinya pengurangan lahan pertanian dan sumber hijauan pakan ternak. ${ }^{1)}$ Melihat kondisi tersebut, maka salah satu pilihan untuk meningkatkan produktivitas ternak adalah memanfaatkan berbagai limbah tanaman pangan. Berbagai limbah yang mempunyai prospek cukup baik dan banyak terdapat dimasyarakat maupun industri pangan saat ini, antara lain : limbah kulit singkong, kulit pisang dan kulit kentang.

Umumnya, sebagian besar limbah limbah pertanian di Indonesia, masih mengandung sumber energi yang cukup tinggi, namun kandungan nitrogennya rendah. Adanya perlakuan fermentasi, bahanbahan tersebut berpotensi sebagai bahan pakan ternak, khususnya ruminansia. ${ }^{2)}$

Kendala dari bahan pakan yang berasal dari limbah adalah : rendahnya nutrien, tidak ekonomis jika digunakan sebagai pakan, tidak tersedia terus menerus, sulit untuk menangani, memerlukan fasilitas tertentu, memerlukan biaya transportasi yang besar dan tidak tahan lama, juga banyak berkontaminasi dengan mikroba beracun ${ }^{3)}$. 
Mikrobiologi dapat mengatasi beberapa masalah tersebut dengan menggunakan mikroba yang akhir-akhir ini mulai digunakan dalam industri pakan. ${ }^{4)}$

Mikrobiologi industri pakan mempunyai peranan dalam memanfaatkan mikroba dalam biosintesis komponen aktif sebagai pemacu perbaikan pakan, pengolahan pakan untuk perbaikan nutrisi dan rekayasa pakan untuk membentuk pakan jenis baru. Beberapa contoh yaitu probiotik, pembuatan slow release amonia, pembuatan $\mathrm{CH}_{4}$ inhibitor, dan sebaginya.

Masalah pemanfaatan mikroba dalam industri pakan ternak tersebut adalah mahalnya teknik pemanenan mikroba dan memerlukan media sehingga tidak ekonomis untuk dijadikan sebagai pakan atau campuran pakan. Untuk hal itu diperlukan teknik khusus melalui manipulasi teknik seperti meniru rumen sebagai biofermentor pada mikrobiologi industri pakan ternak.

Secara umum mikrobiologi industri pakan ternak memiliki syarat-syarat sebagai berikut :

- Mikroba harus mampu tumbuh cepat pada substrat.

- Mampu memecahkan komponen seperti lignoselulosa dan tidak mampu memecahkan organik lainnya yang bisa dimanfaatkan oleh ternak.

- Tidak bersifat parasit bagi lingkungan dan tidak beracun bagi ternak.

- Tumbuh baik dalam kondisi aerobik

- Sebaiknya mikroba yang digunakan berasal dari kelompok jamur karena mudah sebagai inokulat.

- Hindarkan proses sterilisasi karena memerlukan biaya tinggi

- Menggunakan proses fermentasi yang mudah, dan murah serta dapat dengan mudah dilakukan pemanenan mikrobanya.
Pemanfaatan mikroba untuk pengolahan pakan, seperti meningkatkan kecernaan selulosa, meningkatkan kadar nitrogen pakan dapat dilakukan melalui frementasi padat atau semi padat. Cara fermentasi ini dianggap sebagai cara yang mudah dan murah dilakukan.5)

Beberapa sumber bahan baku pakan dari limbah adalah kulit singkong, kulit kentang dan kulit pisang. Secara nutrisi bahan pakan tersebut memiliki kandungan protein yang rendah, sehingga perlu dilakukan usaha manipulasi nutrisi untuk meningkatkan nilai protein bahan pakan tersebut. Manipulasi nutrisi tersebut dapat dilakukan dengan cara mikrobiologi, yaitu memanfaatkan mikroba yang mampu mengeluarkan enzim dan zat lain yang dapat meningkatkan kandungan nitrogen bahan pakan. ${ }^{6)}$

\subsection{Tujuan}

Tujuan Penelitian ini untuk mengetahui peningkatan kandungan protein limbah kulit singkong, kulit kentang dan kulit pisang melalui fermentasi padat (solid fermetation) dengan menggunakan jamur Aspergillus niger, sehingga berpotensi sebagai pakan ternak.

\section{BAHAN DAN METODE}

Penelitian ini dilakukan bekerjasama dengan Fakultas Peternakan IPB selama 8 minggu pada bulan April dan Mei 2007. Analisis Nitrogen dilakukan di Labororium IImu dan Teknologi Pakan Fakultas Peternakan IPB. Fermentasi padat skala laboratorium dilakukan di Laboratorium Mikrobiologi Industri Pakan Fakultas Peternakan IPB.

\subsection{Bahan}

Bahan penelitian yang digunakan yaitu Kulit singkong, kulit kentang dan kulit pisang serta bahan kimia untuk analisis nutrisi, mikrobiologi dan fermentasi padat. Alat yang digunakan yaitu : nampan plastik, sterilisator, tabung reaksi, gelas ukur, gelas kimia, pemanas air, serta alat-alat untuk analisis nitrogen yaitu destilator, pembakar Bunsen dan timbangan mikro Ohause. 


\subsection{Metode Penelitian}

Metode fermentasi padat yang dilakukan dalam penelitian ini adalah sesuai dengan yang disarankan oleh Office de Recherce Scientifique et Technique OutreMer (ORSTOM) dan Institut de Recherce en Chimie Appliquee (IRCHA). ${ }^{7}$ ) Metode ini secara ekonomi sangat menarik karena dapat dikerjakan di pedesaan. Disamping itu keuntungan lain dengan metode ini secara terintegrasi dapat mengurangi masalah transportasi. Seluruh tahap pelaksanaanya dilakukan secara non-aseptik dengan satu buah fermentor yang di modifikasi untuk aerasi, $\mathrm{pH}$ dan pengatur suhu.

Dalam penelitian ini, metode tersebut dikerjakan dengan skala kecil yaitu:

1. Tahap pertama adalah perebusan bahan substrat yaitu singkong, kulit pisang dan kulit kentang pada suhu $75^{\circ} \mathrm{C}$ selama 10 menit.

2. Setelah dingin masing-masing substrat di tambahkan larutan yang mengandung sumber nitrogen (urea dan amonium sulfat), garam-garam mineral, posphate dan spora jamur Aspergillus niger. Jumlah yang diberikannya adalah :

100 - $120 \mathrm{~g}$ air, $\mathrm{SO}_{4}\left(\mathrm{NH}_{4}\right)^{2}$ 9g; urea 2.7 g; $\mathrm{PO}_{4} \mathrm{HK}_{2} 5 \mathrm{~g}$ dan spora jamur yang ditambahkan sebanyak 2 x 107 .

3. Nampan plastik dijadikan sebagai tempat fermentasi, dan fermentasi dilakukan dalam kondisi kadar air $65 \%$ dan $\mathrm{pH} 4.5$ pada suhu $37^{\circ} \mathrm{C}$ selama sembilan hari.

4. Hasil fermentasi (substrat dan kapang) di giling untuk dijadikan tepung (Laru) yang bisa ditularkan kembali ke substrat lain.

5. Pengamatan dilakukan terhadap kadar protein bahan singkong, kulit pisang dan kulit kentang setelah mengalami fermentasi oleh Aspergillus niger. Diamati juga penyebaran pertumbuhan kapang yang fermentasinya menggunakan kapang dalam bentuk tepung (Gambar 1 dan 2 di Lampiran).

Analisis protein kasar dilakukan dengan metode Makro Kjeldahl. Prinsipnya adalah analisis kadar nitrogen $(\mathrm{N})$ dari bahan Contoh. Ada tiga tahap dalam analisis protein kasar ini yaitu :

\section{a). Tahap Dekstruksi}

Prinsipnya yaitu menghilangkan kandungan selain Nitrogen dalam bahan dan mengikat Nitrogen dengan menggunakan $\mathrm{H}_{2} \mathrm{SO}_{4}$ dan proses pemanasan yang menghasilkan molekul $\left(\mathrm{NH}_{4}\right)^{2} \mathrm{SO}_{4}$ yang berwarna hijau jernih kekuningan. Model rumus kimianya sebagai berikut:

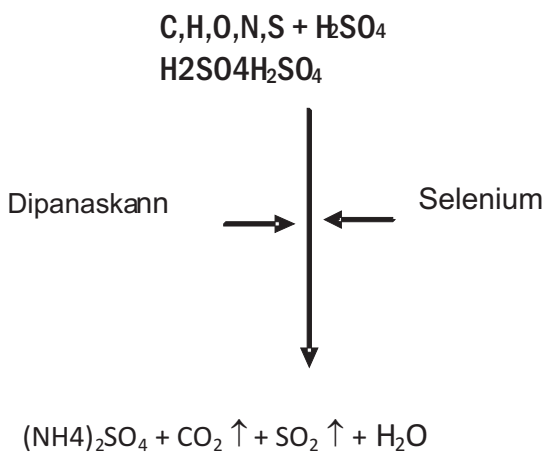

Secara teknis metodenya dilakukan dengan cara menimbang terlebih dahulu contoh kira-kira 0,3 gram (X) dimasukkan ke dalam labu dekstruksi dan ditambahkan katalis selenium sebanyak 3 sendok kecil serta $20 \mathrm{ml} \mathrm{H} 2 \mathrm{SO}_{4}$ pekat teknis secara homogen. Campuran tersebut dipanaskan dengan alat dekstruksi mula-mula pada posisi "low" selama 10 menit, kemudian pada posisi "medium" selama 5 menit dan pada posisi "high" sampai larutan menjadi hijau kekuningan. Proses ini dikerjakan diruang asam.

\section{b). Tahap Destilasi}

Prinsipnya yaitu penyulingan dengan mereaksikan $\left(\mathrm{NH}_{4}\right)^{2} \mathrm{SO}_{4}$ dengan $\mathrm{NaOH}$ 
untuk menghasilkan $\mathrm{NH}_{3}$ sampai semua kandungan nitrogennya terikat oleh $\mathrm{H}_{2} \mathrm{SO}_{4}$ atau sebanyak $2 / 3$ dan membentuk kembali $\left(\mathrm{NH}_{4}\right)_{2} \mathrm{SO}_{4}$. Model rumus kimianya adalah sebagai berikut:

$$
\begin{gathered}
\left(\mathrm{NH}_{4}\right) \mathrm{SO}_{4}+\mathrm{NaOH} \longrightarrow \mathrm{Na}_{2} \mathrm{SO}_{4}+\mathrm{NH}_{4} \mathrm{OH} \\
\mathrm{NH}_{4} \mathrm{OH} \longrightarrow \mathrm{NH}_{3}+\mathrm{H}_{2} \mathrm{O} \\
\mathrm{NH}_{3}+\mathrm{H}_{2} \mathrm{SO}_{4} \longrightarrow\left(\mathrm{NH}_{4}\right)_{2} \mathrm{SO}_{4}
\end{gathered}
$$

\section{c). Tahap Titrasi}

Prinsipnya yaitu menitar kembali kelebihan $\mathrm{H}_{2} \mathrm{SO}_{4}$ pada hasil sulingan dengan menggunakan larutan $\mathrm{NaOH}$. Proses titrasi akan berhenti apabila telah terjadi perubahan warna dari biru kehijauan yang menandakan titik akhir titrasi. Model rumus kimianya adalah sebagai berikut :

$$
\mathrm{H}_{2} \mathrm{SO}_{4}+\mathrm{NaOH} \longrightarrow \mathrm{Na}_{2} \mathrm{SO}_{4}+\mathrm{H}_{2} \mathrm{O}
$$

Penentuan kadar protein kasar adalah sebagai berikut :

$(y-z) \times$ titar $\mathrm{NaOH}$ x $14 \times 6,25 \times 100 \%$

$$
\mathrm{PK}=
$$

$$
\text { Berat Sampel (x) }
$$

\section{HASIL DAN PEMBAHASAN}

Hasil pengamatan peningkatan protein pada limbah kulit singkong, kulit kentang dan kulit pisang dapat dilihat pada Tabel 1 .

Pengamatan kandungan protein kasar bahan setelah fermentasi meningkat dibanding dengan sebelum fermentasi. Peningkatan protein kasar untuk kulit pisang dari $1,0 \%$ menjadi $6,45 \%$ merupakan peningkatan yang cukup signifikan. Begitu pula dengan singkong yang meningkat dari $1,0 \%$ menjadi $8,27 \%$. Hal ini disebabkan karena saat proses fermentasi berlangsung terjadi proses kimia dan fisik terhadap bahan substrat. Seperti degradasi selulosa, pektin, galaktomannan dan sebagainya yang dibantu oleh enzim dari kapang Aspergillus niger. Enzim tersebut merupakan protein yang juga bisa menambah kadar protein kasar bahan produk fermentasi. ${ }^{8)}$ Aktifitasnya dilihat dari aktifitas unit enzim dalam mendegradasi bahan pada kondisi tertentu $\mathrm{pH}$, suhu dan lama fermentasi. Hal ini sangat diperlukan untuk optimalisasi fermentasi.

Tabel 1. Pengamatan pertama : Peningkatan Protein Dengan Fermentasi Padat

\begin{tabular}{|l|c|c|c|}
\hline Substrat & $\begin{array}{c}\text { Protein } \\
\text { Substrat } \\
(\%)\end{array}$ & $\begin{array}{c}\text { pH Fer- } \\
\text { mentasi }\end{array}$ & $\begin{array}{c}\text { Protein } \\
\text { Produk } \\
(\%)\end{array}$ \\
\hline $\begin{array}{l}\text { Kulit } \\
\text { Singkong }\end{array}$ & 1,6 & 4,5 & 8,27 \\
\hline $\begin{array}{l}\text { Kulit } \\
\text { Pisang }\end{array}$ & 1,0 & 4,48 & 6,45 \\
\hline $\begin{array}{l}\text { Kulit } \\
\text { Kentang }\end{array}$ & 5,0 & 4,53 & 8,19 \\
\hline
\end{tabular}

Hasil fermentasi pertama dapat digunakan sebagai substrat untuk medium pertumbuhan Aspergillus niger. Kemudian hasil fermentasi tersebut digunakan sebagai laru (substrat + kapang yang telah digiling) untuk fermentasi kedua. Pengamatan penyebaran pertumbuhan Aspergillus niger hasil fermentasi kedua seperti pada Tabel 2. Pengamatan produk fermentasi dengan menggunakan produk fermentasi sebelumnya atau laru (substrat + kapang yang telah digiling) dilakukan pada pengamatan penyebaran pertumbuhan koloni kapang secara kualitatif dan nilai keasaman $(\mathrm{pH})$ setelah fermentasi. Parameter tersebut akan memberikan gambaran efektifitas laru dengan substrat berbeda.

Dari hasil pengamatan pada fermentasi kedua, terlihat bahwa Laru yang menggunakan substrat kulit pisang baik digunakan pada substrat kentang singkong dan kulit pisang. Sedangkan laru singkong untuk substrat kulit pisang menghasilkan penyebaran hasil fermentasinya yang tidak baik. Demikian pula dengan laru kulit kentang yang difermentasikan ke subsrat kulit pisang. Secara visual pengamatan kualitatif penyebaran koloni kapang seperti pada Gambar 2 di Lampiran. 
Tabel 2. Pengamatan kedua : Penyebaran Produk (substrat terfermentasi Aspergillus niger) sebagai Laru pada Bahan Pakan

\begin{tabular}{|c|l|c|c|}
\hline Bahan Pakan & \multicolumn{1}{|c|}{ Laru } & $\mathrm{PH}$ & Penyebaran \\
\hline Kulit Kentang & Substrat Kulit Kentang & 4,64 & ++ \\
\hline & Substrat Singkong & 4,63 & +++ \\
\hline & Substrat kulit pisang & 4,42 & + \\
\hline Kulit Singkong & Substrat Kulit Kentang & 4,43 & +++ \\
\hline & Substrat Singkong & 4,30 & +++ \\
\hline & Substrat kulit pisang & 4,21 & + \\
\hline Kulit Pisang & Substrat Kulit Kentang & 4,49 & +++ \\
\hline & Substrat Singkong & 4,51 & +++ \\
\hline & Substrat kulit pisang & 4,41 & +++ \\
\hline
\end{tabular}

Kapang Aspergillus niger diketahui dapat menghasilkan enzim-enzim spesifik sesuai dengan komponen dominan substratnya. ${ }^{9)}$ Secara industri telah diproduksi beberapa hasil fermentasinya secara murni melalui kapang ini. Hal ini dapat dilakukan karena mudah prosesnya dan mampu menjadi bahan aditif pakan untuk meningkatkan mutu pakan rendah nitrogen. ${ }^{10)}$ Sebagai kendala adalah adanya sifat beracun dari kapang Aspergillus niger dan dapat menimbulkan penyakit aspergillosis pada manusia (alergi). ${ }^{11)}$

Dari sekian banyak ekspose yang menggunakan kapang ini hanya ada beberapa laporan mengenai aspergillosis di Nigeria serta satu laporan kasus Otomycosis akibat kapang ini. Akan tetapi produksi mycotoksin harus dikontrol melalui kondisi saat fermentasi. ${ }^{12)}$

Bahaya terhadap hewan telah dijelaskan karena pengaruh mycotoksin yang dihasilkan oleh Aspergillus niger, seperti kekurangan Kalsium dan sifat fisiologis abnormal lainnya termasuk kematian yang dapat terjadi sehubungan dengan produksi oxalic acid atau malformins dari Aspergillus. ${ }^{13)} \mathrm{Hal}$ ini pun telah dikaji tidak berpengaruh secara signifikan sebagai pathogen bagi ternak jika dikontrol fermentasinya. Pemanfaatan Aspergillus niger untuk fermentasi bahan pakan telah dilaporkan ${ }^{14}$ dengan menggunakan dedak padi untuk menghilangkan kandungan asam pitat yang menjadi penghambat ketersediaan nutrien dedak padi, karena Aspergillus niger dapat menghasilkan enzim pitase yang dapat melepaskan ikatan asam pitat terhadap mineral dan protein yang terikat oleh asam pitat

\section{KESIMPULAN}

Kapang Aspergillus niger dapat meningkatkan kandungan protein bahan pakan dari limbah kulit singkong, kulit pisang dan kulit kentang secara signifikan. Peningkatan nutrien tersebut akibat proses fermentasi yang menghasilkan beberapa produk seperti enzim, mineral organik dan pemecahan-pemecahan komponen nutrien yang sulit untuk didegradasi.

Bahan limbah pertanian seperti kulit pisang dan kulit kentang dapat pula dijadikan laru sebagai substrat untuk kapang Aspergillus niger. Penyebaran koloni Aspergillus saat fermentasi dengan menggunakan bahan limbah tersebut adalah baik dan menyebar rata, sehingga diduga akan dapat terjadi ferementasi yang optimal, murah dan mudah untuk dilakukan.

Pengaruh dari penggunaan kapang Aspergillus niger terhadap manusia dan lingkungannya telah dikaji tidak signifikan, akan tetapi perlu dikontrol terhadap kondisi saat fermentasinya. 


\section{DAFTAR PUSTAKA}

1. Hanafi, N.D., 2004. Perlakuan silase dan amoniasi daun kelapa sawit sebagai baku pakan domba. Fakultas Pertanian Program studi Produksi Ternak Universitas Sumatera Utara.

2. Fardiaz, S., 1998. Teknologi Fermentasi. Jurusan teknologi Pangan dan Gizi. Fakultas Pertanian - IPB. Bogor.

3. Donna, M., Amaral-Philips, A., and Hemken, R.W., 1998. Using Byproducts to Feed dairy cattle. Publication. www.ca.uky.edu/agc/asc/ asc136/asc136.htm.

4. El Bousy, A. R. Y., and Van der Poel, A. F. B., 1997. Poultry Feed Form Waste. Chapmann and Hall Press. London. UK

5. Senez, J., 1983. Protein Enrichment of Starchy Materials By Solid State Fermentations. Proceeding on production and Feeding of Single cell Protein. Appl. Sci. Publ. London and New york.

6. Galas, E., PYC, R., Romanowska, L., 1997. Hydrolisis and Transformatioon of Cellulose with Aspergillus niger IBT - 90 Enzymes. Acta Biotechnologica. Vol. 17(1997) no.4 pp. 339-350. WILEYVCH Verlag Berlin.

7. Suryahadi. 1998. Metodologi Penelitian Bioteknologi Nutrisi Ruminansia. Materi Pelatihan Met \& Manajemen Bidang Peternakan Universitas Mataram, NTB.
8. Chalal, D.S., 1985. Solid State fermentation with Tchoderma reeseifor Cellulosa production. Appl. Envirnm. Microbiol. 49 : 205-210.

9. Ademark, P., 2000. Galactoglucomannan Degrading enzymes from Aspergillus niger. Disertation. Faculty of Science. Lund University. Sweden.

10. Munarso, S. J., 1989. Produksi Amilase dari kapang Aspergillus awamori var kawachi pada substrat dedak untuk pembuatan tepung beras kaya protein.

11. Tcacenco, L., Stefana, J., Serban, M., Teodore, E., 1997. Glucoxidase from Aspegills niger Immobilized on Collagen Membrane. Romanian Journal of Biological Science. 1-2, p. 38-42. Bucharest.

12. Wasay, S. A., Barrington, S. and Tokunaga, S., 1998. Using Aspergillus niger to Bioremediate soils contaminated by heavy metals. Bioremedation Journal, vol. 2, no. 3 \& 4, pp $183-190$.

13. Austwick, P.K.C., 1965. Pathogenity of Aspergillus species. pp. 82126. Ln L.B. raper and DI.

14. Refnita, 1990. Pengaruh Penggunaan Dedak padi yang difermentasi dengan Aspergillus niger dalam ransum dengan serat kasar tinggi terhadap penampilan produksi dan ketersediaan mineral P,Ca dan Mg Ayam Pedaging. Tesis Pasca Sarjana IPB, Bogor 
a

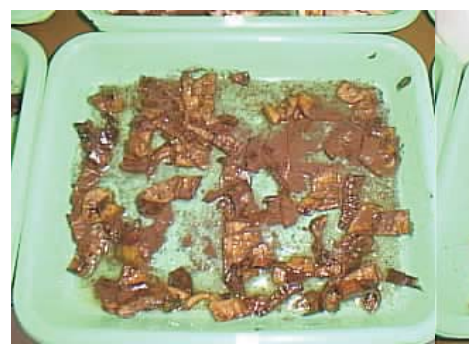

b

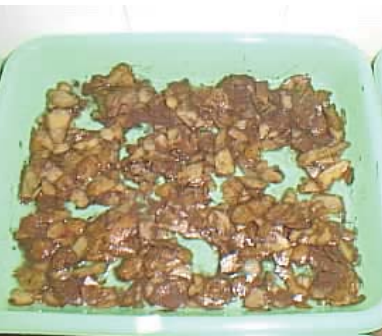

C

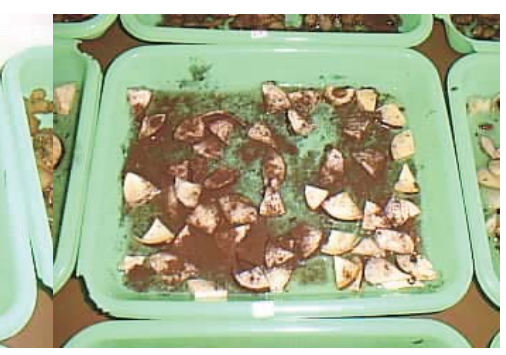

Gambar 1. Fermentasi substrat kulit pisang (a) kulit kentang (b) singkong (c)
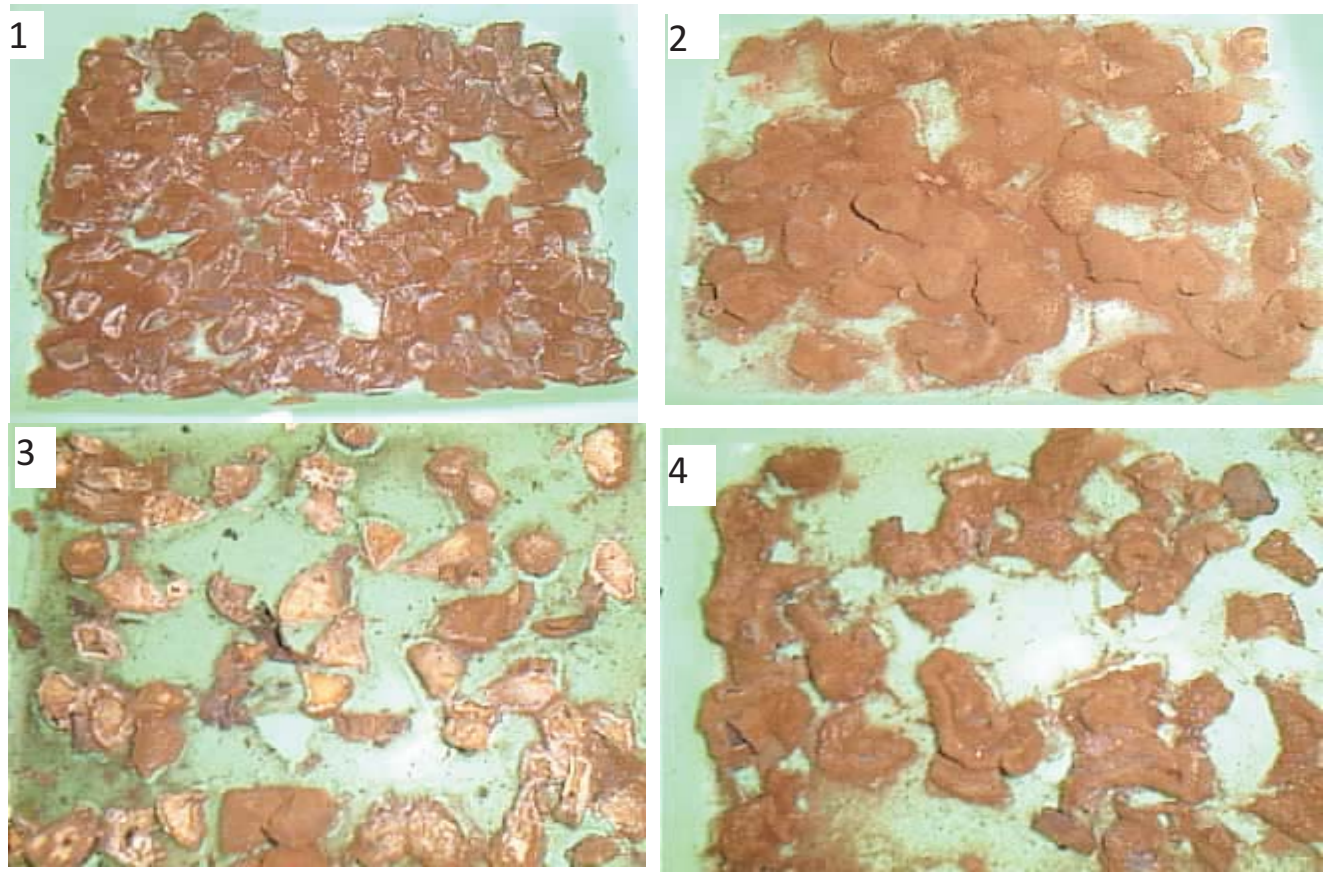

Gambar 2. Penyebaran kapang setelah fermentasi dengan menggunakan Laru hasil fermentasi pertama : Laru kentang substrat kentang (1) Laru singkong ' substrat singkong (2) Laru kentang substrat singkong (3) Laru kentang substrat kulit pisang 


\title{
JURNAL TEKNOLOGI LINGKUNGAN
}

ISSN : 1441 - 318X

Akreditasi :

Skep Kepala LIPI No. 1417/D/2006

Kpts Dirjen Dikti Depdiknas RI No. 34/DIKTI/Kep/2003

Alamat Redaksi : Pusat Teknologi Lingkungan

Gedung BPPT II Lantai 20, Telp. 0213169755 Faks. 0213169760

\section{Undangan Menulis}

JTL, Jurnal Ilmiah Terakreditasi terbit 3X setahun memberi kesempatan bagi Anda untuk mempublikasikan temuan dan pemikiran yang berkaitan tentang penguasaan IPTEK bidang Teknologi Pengembangan Sumberdaya Alam.

\author{
Informasi Pendaftaran \\ dan Penerimaan Makalah:
}

Diyono

Gedung II Lantai 20 Telp. 3169755 